\title{
EXPERIMENTÁLNÍ OVĚŘENÍ DODATEČNÉHO PROVÁDĚNÍ OTVORU DO ŽELEZOBETONOVÝCH STĚN
}

\author{
EXPERIMENTAL VERIFICATION OF MAKING AN ADDITIONAL \\ OPENING TO THE REINFORCED CONCRETE WALLS
}

\author{
Ondřej Šimek ${ }^{*}, 1$, Miloš Zich ${ }^{1}$, Michal Požár ${ }^{1}$, Radim Nečas $^{1}$
}

*simek.o@fce.vutbr.cz

${ }^{1}$ Vysoké technické v Brně, Fakulta stavební, Veveří 331/95, 60200 Brno

\begin{abstract}
Abstrakt
Předmětem článku je uvedení výsledků experimentů prefabrikovaných železobetonových stěn, do kterých byl dodatečně vyřezán otvor za současného působení zatížení. Jedná se o stěny, které simulují běžnou stěnu $\mathrm{v}$ panelovém domě, do které je dodatečně proveden otvor. Stěny jsou vyztuženy různými variantami: od jednoduchého vyztužení kari sítí, po vyztužení standartní výztuží po obvodě, v nadpraží i pilírích. Je tak studován i vliv tzv. „spící výztuže“, tj. výztuže, která je v panelu předem připravena pro případ dodatečného provedení otvoru. Je studován vliv této výztuže na rozvoj trhlin a změn poměrných přetvoření na panelu po vyřezání otvoru. $\mathrm{V}$ rámci experimentu je sledováno i dlouhodobé chování panelů s dodatečně provedeným otvorem.
\end{abstract}

\section{Klíčová slova}

Železobetonová stěna, vyztužení, konstrukční zásady, dodatečný otvor

\begin{abstract}
The subject of the article is to present the results of experiments of prefabricated reinforced concrete walls that were loaded prior to the making of an additional opening. These are walls that simulate a regular wall in a wall panel building, into which an additional opening is made. The walls are reinforced with different variants of reinforcement: from simple reinforcement with wire mesh to standard reinforcement around the perimeter, in the lintel and the pillars. The influence of so called "sleeping reinforcement" is studied. This reinforcement is preprepared in the panel for the case of making an additional opening. The effect of this reinforcement on the development of cracks and changes in strain on the panel after making the additional opening is studied. Long term monitoring of the panels with newly made opening is also conducted as a part of the experiment.
\end{abstract}

\section{Key words}

Reinforced-concrete wall, reinforcement, detailing of reinforcement, additional opening

\section{1 ÚVOD}

V běžných stavbách prefabrikovaných panelových objektů bytové výstavby jsou nosné stěny namáhány převážně svislým tlakem s malou excentricitou. Tento způsob zatížení umožňuje návrh stěnových panelů z prostého, př́padně ze slabě vyztuženého betonu [1]. V současné době je často třeba do existujícího stěnového panelu vyřezat otvor za účelem uvolnění dispozice. Následně musí statik mimo jiné řešit přenesení ohybových účinků vznikajících v nadpraží a posoudit vzniklé betonové pilíře, které obvykle nesplňují konstrukční zásady pro sloupy a stěny (např. svislá výztuž je u vnějšího průřezu a není obepnuta třmínky, absentují spony apod.) dle požadavků norem [2].

Pro ověření namáhání tohoto typu stěn bylo navrženo 5 samostatných typů, které byly různě vyztuženy s označením ZP01 až ZP05, viz Obr. 2 a Tab. 1. Vzorky byly rozměru $1600 \times 1400 \times 75 \mathrm{~mm}$, tedy v měřítku $1: 2$ vůči skutečné stěně. Tyto samostatné stěny simulují případ, který může vzniknout po vyřezání otvoru ve stěnovém panelu. Na stěnových prvcích byl vyzkoušen postup dodatečného vyřezávání otvoru již zatížené stěny a současně byl zkoumán vliv vhodného vyztužení stěn pomocí tzv. „spící výztuže“. To je výztuž, která začne působit až po dodatečném provedení otvoru. Cílem bylo také získat relevantní data $\mathrm{k}$ ověření vhodného způsobu vyztužování 
obdobných stěn nových staveb. Stěny byly vyzkoušeny v laboratořích AdMaS na VUT, viz Obr. 1. Získaná experimentální data byla poté použita k vyhodnocení a srovnání chování jednotlivých stěn.

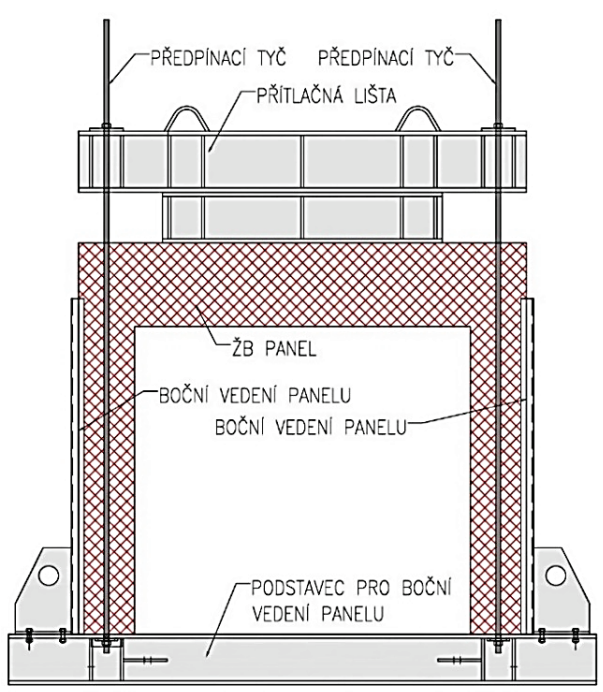

Obr. 1 Schéma experimentu.

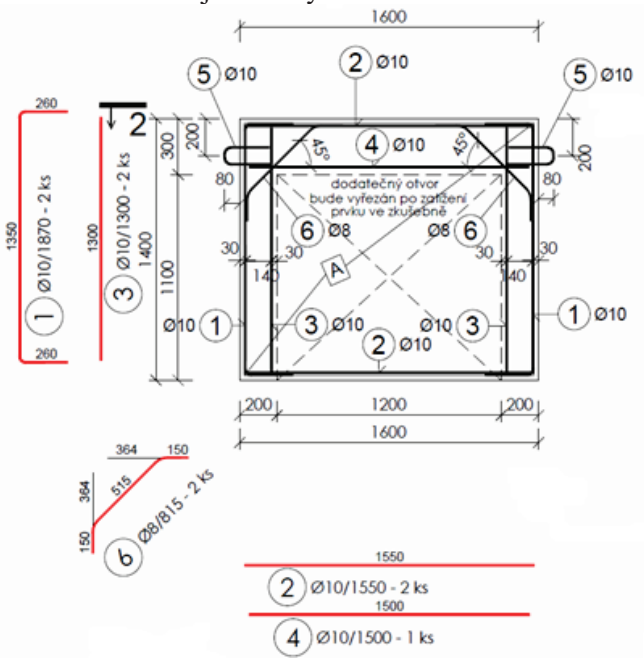

Obr. 2 Vyztužení zkušebních panelů.

Tab. 1 Vyztužení jednotlivých variant stěnových dílců.

\begin{tabular}{cccccc}
\hline $\begin{array}{c}\text { Stěnový } \\
\text { dílec }\end{array}$ & Plošná výztuž & $\begin{array}{c}\text { Vnější obvodová } \\
\text { lemujíí výztuž }\end{array}$ & $\begin{array}{c}\text { Výztuž } \\
\text { nadpraží }\end{array}$ & $\begin{array}{c}\text { Vnitřní svislá } \\
\text { výztuž rámu }\end{array}$ & $\begin{array}{c}\text { Rohová šikmá } \\
\text { výztuž }\end{array}$ \\
\hline ZP01 & $\varnothing 6 / 100+\varnothing 6 / 100$ & - & - & - & - \\
ZP02 & $\varnothing 6 / 100+\varnothing 6 / 100$ & (1) (2) $1 \varnothing 10$ & - & - & - \\
ZP03 & $\varnothing 6 / 100+\varnothing 6 / 100$ & (1) (2) $1 \varnothing 10$ & (4) $1 \varnothing 10$ & - & - \\
ZP04 & $\varnothing 6 / 100+\varnothing 6 / 100$ & (1) (2) $1 \varnothing 10$ & (4) $1 \varnothing 10$ & (3) $1 \varnothing 10$ & - \\
ZP05 & $\varnothing 6 / 100+\varnothing 6 / 100$ & (1) (2) $1 \varnothing 10$ & (4) $1 \varnothing 10$ & (3) $1 \varnothing 10$ & (6) $1 \varnothing 8$ \\
\hline
\end{tabular}

\section{LITERÁRNÍ PřEHLED/POPIS SOUČASNÉHO STAVU}

Dodatečnému provádění otvorů do panelových objektů se v České republice věnoval především Witzany [3] a [4], kde byla tato problematika řešena po praktické i teoretické stránce. V těchto studiích byl prověřován vliv polohy dodatečných otvorů na výseku panelové stěny, Obr. 3. Rovněž byly prezentovány i některé postupy, které slouží k posouzení stěny s dodatečně provedeným otvorem.

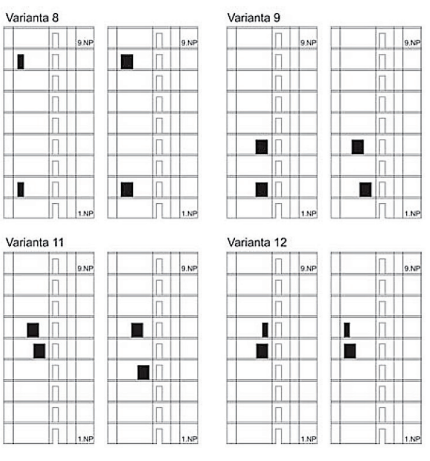

Obr. 3 Varianty polohy otvorů [3].

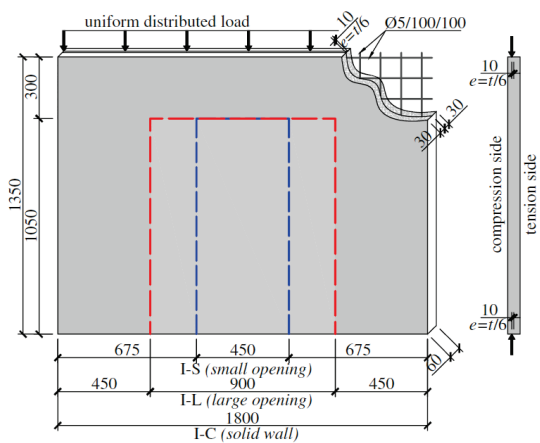

Obr. 4 Experimentální vzorky [5]. 
Experimentálnímu ověření dodatečného provedení otvoru byla věnována pozornost v [5] a [6]. V rámci experimentů byl prověřován vliv velikosti otvoru na únosnost a napjatost stěny, která byla zatížena svislým rovnoměrným zatížením s excentricitou e $=$ t/6 (běžné zatížení v panelovém domě). Experimentální vzorky byly vyztuženy pouze KARI sítěmi $\varnothing 5 / 100+\varnothing 5 / 100$, viz Obr. 4. Výsledky byly poté ověřovány výpočetními postupy. Získané výsledky byly použity k statické analýze části budovy s dodatečně prováděnými otvory.

Praktické zkušenosti a doporučení k provádění dodatečných otvorů do stěn panelových objektů je popsáno např. v [7].

\section{EXPERIMENTÁLNÍ OVĚŘENÍ}

\section{Popis zkoušky}

Bylo vyzkoušeno celkem 10 zkušebních stěn, tedy 2 kusy od každého typu stěny. Vždy se zkoušely současně 2 vzorky. Experimenty stěn byly provedeny následovně: panely, které byly vybaveny měřičskými senzory byly osazeny do zkušebního rámu, poté byl na panel osazen roznášecí nosník se čtyřmi předpínacími tyčemi, pomocí kterých se roznášecí nosník sepnul se zkušebním rámem. Tímto postupem se na panel aplikovalo zatížení, Obr. 5. Na spodní i horní hranu panelu bylo provedeno podmazání cementovou směsí, která vyrovnala veškeré nerovnosti, které by mohly vzniknout při zatěžování a osazování panelu. V patách budoucích pilírù bylo zabráněno vodorovnému posuvu, to bylo zajištěno větší vrstvou podmazání na vnějším líci budoucích pilírủ. Díky tomuto bylo vytvořeno tzv. ,rámové působení konstrukce“.

Zkoušky měly dvě varianty: pro krátkodobé a pro dlouhodobé sledování chování panelu. Rozdíly byly ve velikosti aplikovaného zatížení a v délce sledování chování panelu po vyřezání otvoru v čase. Pro krátkodobé sledování byly data odečítána max. do 7 dnů od vyřezání. Pro dlouhodobé chování byly data odečítána až do 87 dnů po vyřezání.

Volba velikosti zatížení pro provedený experiment vychází přibližně ze zatížení na jeden metr délky běžné stěny ve čtyřpodlažním panelovém domě, tj. bylo uvažováno $f_{\mathrm{d} \text {,panel }}=160 \mathrm{kN} / \mathrm{m}$. To přestavuje rovnoměrné tlakové napětí ve běžné stěně panelového domu -1,1 MPa, viz Tab. 2 vztah (1). Při uvažování nově vzniklých pilířru o širřce $400 \mathrm{~mm}$ je po vyřezání otvoru v napětí o hodnotě $-4,3 \mathrm{MPa}$, viz Tab. 2 vztah (2).

Pro model 1:2 bylo zvoleno zatížení $4 \times 40 \mathrm{kN}=160 \mathrm{kN}$, to představuje normálové napětí ve stěně $-1,3 \mathrm{MPa}$, viz Tab. 2 vztah (3). Na pilír poté připadá síla $80 \mathrm{kN}$. Normálové napětí betonu na nově vzniklém pilíři je tedy 5,3 MPa, viz Tab. 2 vztah (4). Napětí jsou počítána pouze přibližnou metodou za účelem zjištění experimentální síly pro namáhání zkušebních vzorků.

Tab. 2 Odvození zatěžovací síly pro experiment.

\begin{tabular}{|c|c|c|c|}
\hline \multicolumn{2}{|c|}{ Stěna } & Výpočetní vztah & Ozn. \\
\hline $\begin{array}{c}\text { Stěna ve skutečné } \\
\text { budově: }\end{array}$ & $\begin{array}{l}\text { Před vyřezáním } \\
\text { otvoru }\end{array}$ & $\begin{array}{c}\sigma_{c, \text { skut }, \text { panel }}=\frac{f_{d, \text { panel }} \cdot b}{b \cdot t_{\text {skut }}}=\frac{160 \cdot 10^{-3} \cdot 1,0}{1,0 \cdot 0,15} \\
=-1,1 \mathrm{MPa}\end{array}$ & (1) \\
\hline$(3,2 \times 2,8 \times 0,15)$ & $\begin{array}{l}\text { Po vyřezání otvoru } \\
\text { (pilířr šíŕky } 400 \text { mm) }\end{array}$ & $\sigma_{c, \text { skut,pilír }}=\frac{F_{\text {piliŕ }}}{A_{\text {piliŕ }}}=\frac{256}{0,15 \cdot 0,4}=-4,3 \mathrm{MPa}$ & (2) \\
\hline Experimentální & $\begin{array}{l}\text { Před vyřezáním } \\
\text { otvoru }\end{array}$ & $\sigma_{c, \text { exp }, \text { panel }}=\frac{F_{\text {exp }}}{A_{\text {panel }}}=\frac{160 \cdot 10^{-3}}{0,075 \cdot 1,6}=-1,3 \mathrm{MPa}$ & (3) \\
\hline $\begin{array}{c}\text { Vzorek: } \\
(1,6 \times 1,4 \times 0,075)\end{array}$ & $\begin{array}{l}\text { Po vyřezání otvoru } \\
\text { (pilíŕ šířky } 200 \text { mm) }\end{array}$ & $\sigma_{c, \text { exp }, p i l i \text { r }}=\frac{F_{\text {pilír }} / 2}{A_{\text {piliŕ }}}=\frac{160 / 2}{0,075 \cdot 0,2}=-5,3 \mathrm{MPa}$ & (4) \\
\hline
\end{tabular}

V modelu 1:2 jsou tedy zvoleny síly vyvozující mírně vyšší normálové napětí než u stěny v měřítku 1:1. Síle $160 \mathrm{kN}$ byly podrobeny vzorky 2×ZP02, 2×ZP03, 2×ZP04 a jeden vzorek ZP05. Pro dlouhodobé sledování byly vybrány vzorky $1 \times \mathrm{ZP0} 1$ a $1 \times \mathrm{ZP} 05$. Hodnota zatížení těchto vzorků byla zvolena $100 \mathrm{kN}$. Představuje to cca kvazistálou složku celkového zatížení.

Předpínací tyče byly na horní i spodní hraně ukotveny kotevními deskami s maticemi. Napínání bylo provedeno pomocí hydraulického lisu přes napínací „hrnec“ a následovným utažením matice.

Každý panel byl osazen 6-ti odporovými tenzometry a 5-ti strunovými tenzometry pro snímaní změn poměrného přetvoření a rozvoje trhlin na panelu při vyřezávání otvoru, viz Obr. 8. Každá předpínací tyč byla rovněž vybavena dvěma odporovými tenzometry, pomocí kterých se snímala síla v tyči při napínaní a vyřezávání otvoru do panelu. Pro kontrolu správnosti měřené síly byly na dvě tyče umístěny siloměry. Rozmístění všech čidel je popsáno na Obr. 7. Celý průběh všech zkoušek byl zaznamenáván na ústředny QuantumX a Datataker. Odporové tenzometry na panelech a tyčích a siloměry byly napojeny do celkem tř́i ústředen QuantumX, kde byla 
data odečítána každou 1 vteřinu. Strunové tenzometry byly napojeny do ústředny Datataker, který odečítal data každých 10 vteřin.

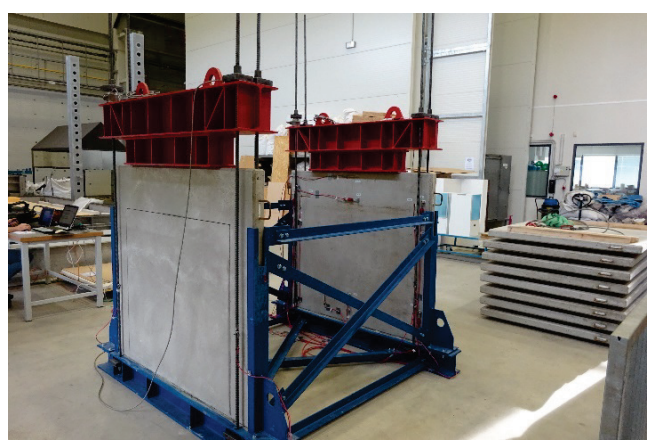

Obr. 5 Před vyřezáním otvoru.

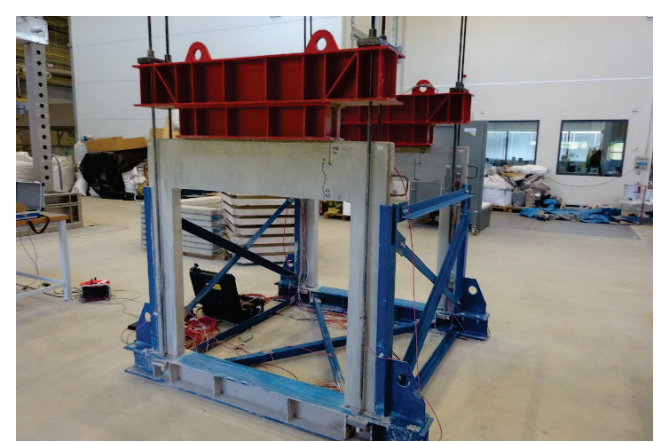

Obr. 6 Po vyřezání otvoru.

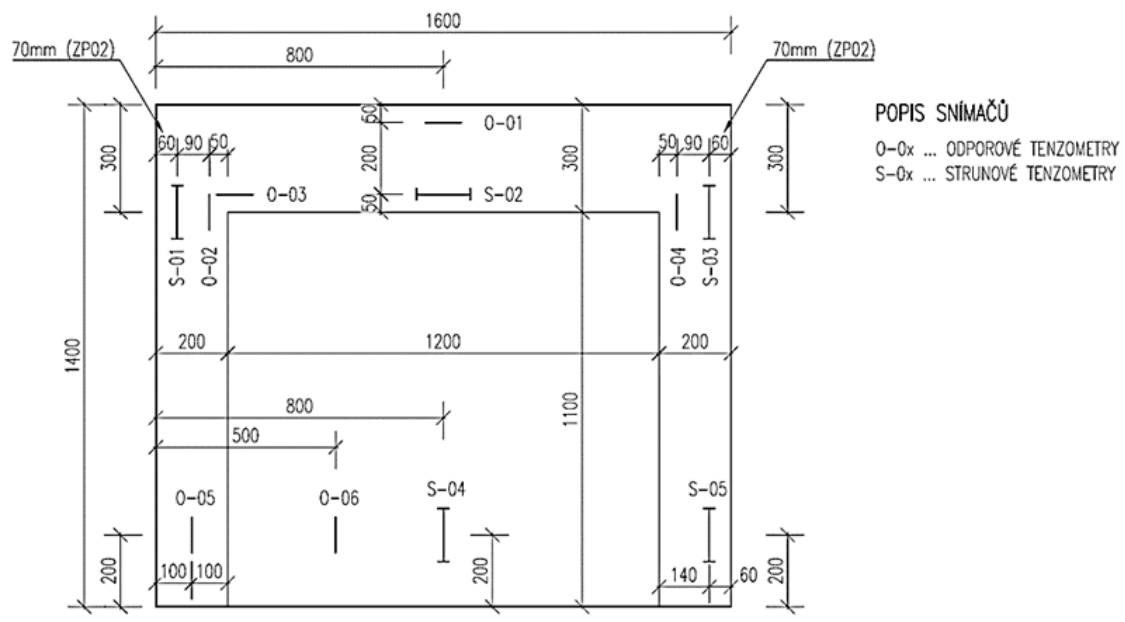

Obr. 7 Rozmístění snímačů.

\section{Průběh zkoušek}

Po osazení panelů do zkušebního rámu se provádělo napínání předpínacích tyčí a tím bylo vyvozeno zatížení na panely. Tyče se napínaly po prŕrůstcích cca $10 \mathrm{kN}$ tak, aby aplikace zatížení byla rovnoměrná.

Následující den (po ustálení napětí v panelu) následovalo řezání otvoru do panelu. Prvně se provedlo šest jádrových vývrtů do panelu ( 4 v rozích a 2 v horní polovině uvnitř budoucího otvoru, vždy ve stejném pořadí), poté následovalo řezání (také vždy ve stejném pořadí). Řezání bylo provedeno pomocí řezačky s diamantovým kotoučem, Obr. 6.

Změny poměrného přetvoření byly zaznamenávány během celého řezání do panelu. Po vyřezání byl zaznamenán pokles sil v tyčích, a to cca o $10 \mathrm{kN}$ na jednu tyč (pokles ze $40 \mathrm{kN}$ na $30 \mathrm{kN}$, resp. ze $25 \mathrm{kN} \mathrm{na} 18 \mathrm{kN}$ ). Tento pokles síly lze vysvětlit vlivem deformace nově vzniklého nadpraží spolu se stlačením nové vzniklých piliŕů a tím zkrácení délky tyčí. Kvůli tomuto jevu bylo nutné tyče dopnout po vyřezání. Hodnotu poměrného přetvoření tenzometrů po dopnutí tyčí lze brát jako reprezentativní. Ukazuje změnu poměrného přetvoření betonu po vyřezání. Dále byly odečteny hodnoty šiřrek trhlin pomocí strunových tenzometrů a příložných měřítek. Odečty dat, tedy změn poměrného přetvoření betonu a šířek trhlin byly provedeny do 7 dnů po vyřezání pro krátkodobé zkoušení do 87 dnů pro dlouhodobé zkoušení. 
Pro zjištění materiálových charakteristik byly ke zkušebním panelům vyhotoveny i zkušební tělesa (3 krychle a 5 trámců). Stáří panelů v době zkoušek bylo 197 až 238 dní, stáří zkušebních těles bylo 258 a 261 dní. Lze říci, že u takto vyzrálého betonu lze uvažovat pevnosti betonu panelu stejné, jako pevnosti zkušebních těles, tzn. není nutný přepočet na základě stáří betonu. Zjištěná průměrná krychelná tlaková pevnost betonu pro čas zkoušení panelů byla 71,2 MPa, tahová pak 4,1 MPa. Modul pružnosti betonu byl naměřen 29,3 GPa.

\section{VYHODNOCENÍ VÝSLEDKŮ}

\section{Změna poměrného přetvoření betonu po vyřezání}

V následující kapitole jsou prezentovány hodnoty změn poměrných přetvoření betonu $\Delta \varepsilon_{\mathrm{c}} \mathrm{v}$ jednotlivých stádiích působení konstrukce. Některá data $\mathrm{v}$ následujících grafech chybí z důvodu poruchy odečtu snímačů nebo poškození snímače trhlinou (odporové tenzometry).

Stav napjatosti v zatížené stěně bez otvoru je tzv. „,nulový“. Změny poměrných přetvoření v grafech znázorňují pouze změnu oproti stavu před vyřezáním otvoru.

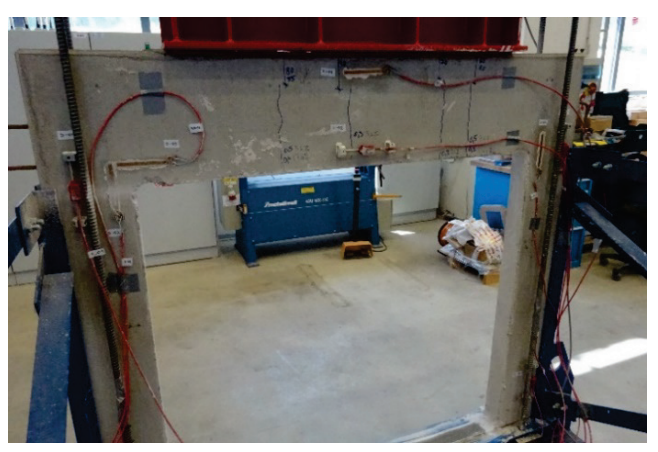

Obr. 8 Panel ZP02 - pohled zezadu (osazení snímačů).

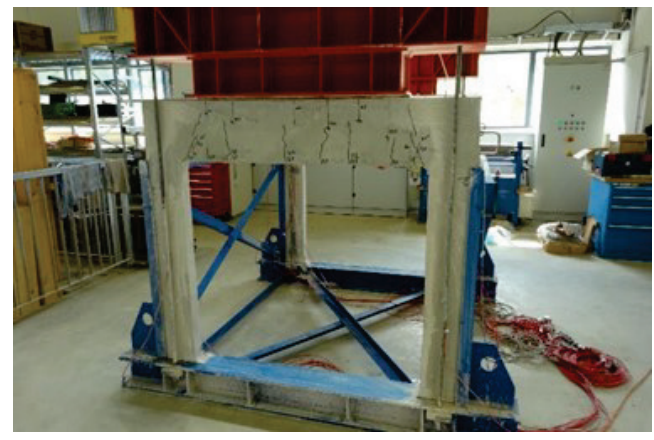

Obr. 9 Panel ZP03 po vyřezání otvoru.

Na Obr. 10 až Obr. 12 je vyobrazen průběh změn poměrných v jednotlivých měřičských bodech pro časový interval těsně po vyřezání otvoru až 7 dnů po vyřezání pro panely zatížené silou $160 \mathrm{kN}$. Je zřejmé, že díky dotvarování betonu, přetvoření v betonu v průběhu času nadále stoupá. Největší přírůstky lze sledovat pro všechny př́ípady panelů na bodech O-02 a O-04, tedy na vnitřní hraně pilířu. Zde se přetvoření pro ZP02 zvýšilo průměrně o $30 \%$ oproti hodnotám po vyřezání. Pro ZP04 se přetvoření zvýšilo po 7 dnech průměrně o $10 \%$. Přetvoření v patách pilírư (snímače O-05 a S-05) se drželo přibližně na stejné hodnotě v průběhu sledování pro všechny panely, stejně tak jako na snímači O-03. Teplota se v průběhu zkoušení panelů ZP02 a ZP03 držela na $22-23{ }^{\circ} \mathrm{C}$, v př́ípadě ZP04 a ZP05 byla teplota pak $23,5-24,5^{\circ} \mathrm{C}$.

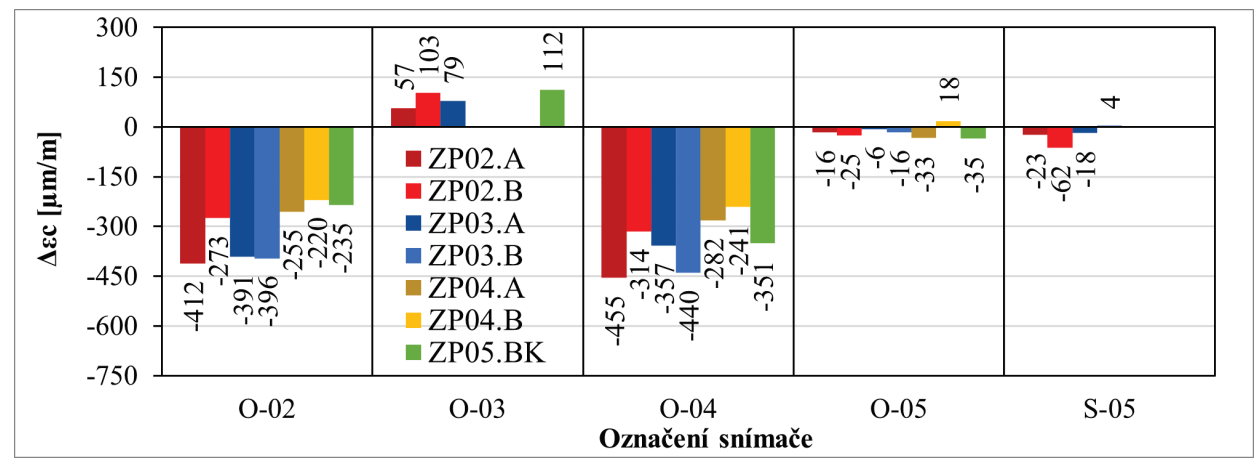

Obr. 10 Změna poměrného přetvoření v betonu bezprostředně po vyřezání otvoru (síla 160 kN). 


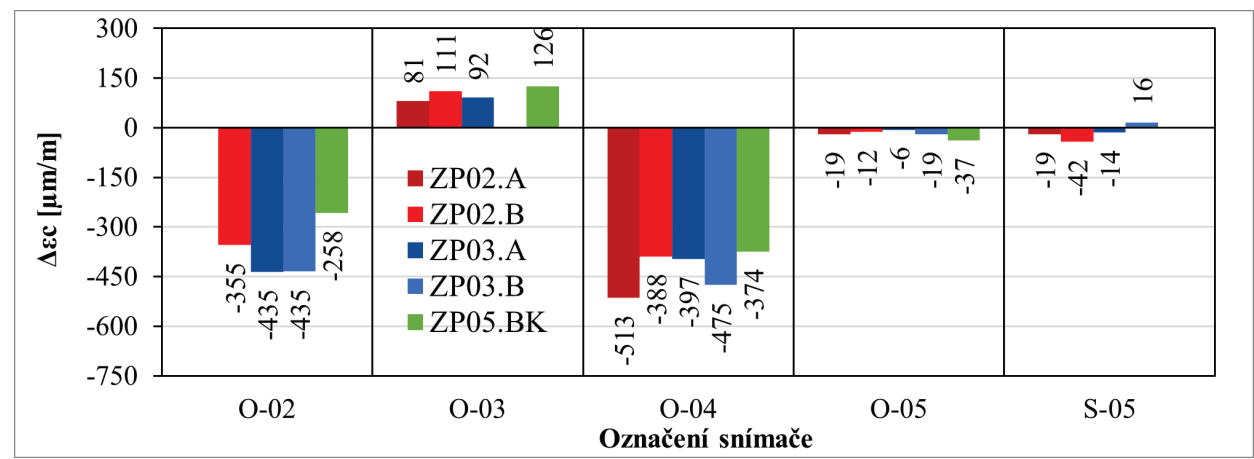

Obr. 11 Změna poměrného přetvoření v betonu 1 (2) dny po vyřezání otvoru (síla 160 kN).

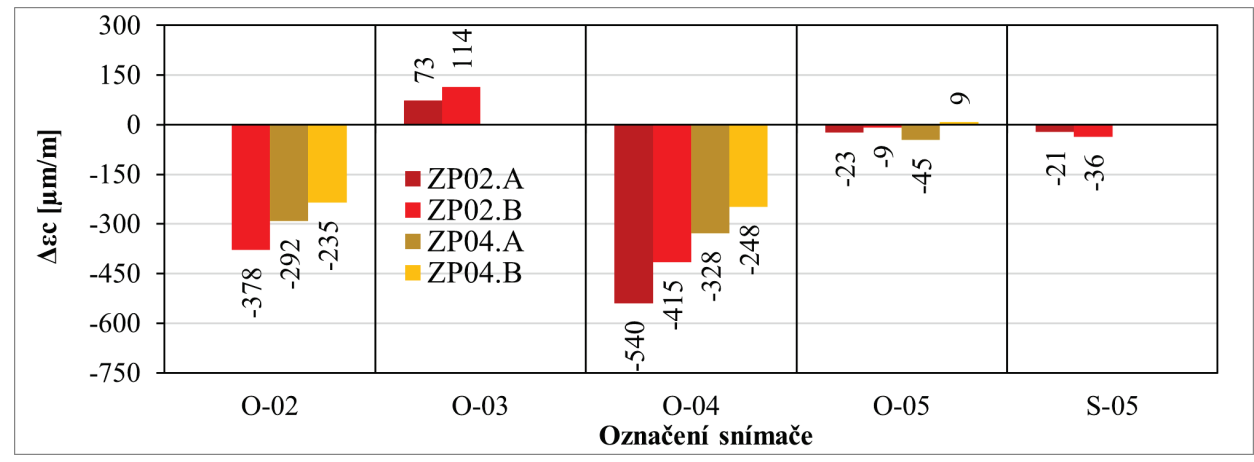

Obr. 12 Změna poměrného přetvoření v betonu 6 (7) dnů po vyřezání otvoru (síla 160 kN).

Dále na Obr. 13 až Obr. 15 je vyobrazen průběh změn poměrných přetvoření pro variantu experimentu „dlouhodobé sledování“ (zatížení 100 kN) do času až 30 dnů po vyřezání. Snímače O-02 a O-04 ukázaly nárůst přetvoření průměrně o $80 \%$ pro ZP01, pro ZP05 byl nárůst průměrně $65 \%$. Snímač O-05 v patě pilíře ukázal nárůst až o 200 \% pro ZP01 v průběhu sledování, pro ZP05 se bohužel nepodařilo obdržet data. Přetvoření na bodě O-03 je po vyřezání otvoru tahové pro oba případy. Pro panel ZP01 se přetvoření z původní hodnoty $80 \mu \mathrm{m} / \mathrm{m}$ po vyřezání přetvoření snížilo skoro na nulovou hodnotu (stav před vyřezáním otvoru). Avšak pro panel ZP05 se přetvoření drželo v cca ustálené hodnotě (pokles $11 \%$ ). Do konce sledování ( 87 dnů po vyřezání) se přetvoření měnilo jen minimálně. Teplota byla v průběhu zkoušení panelů mezi $23-24{ }^{\circ} \mathrm{C}$.

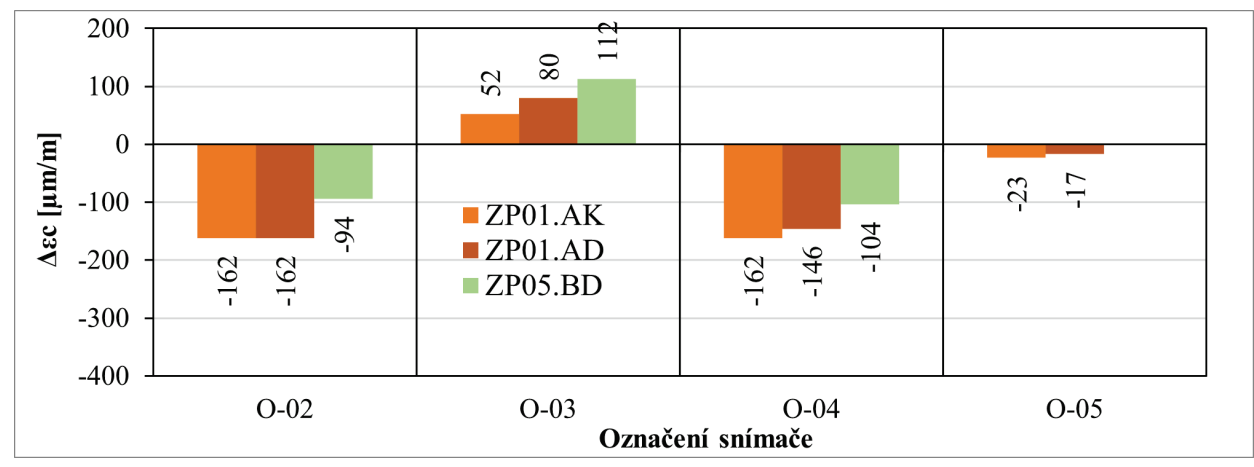

Obr. 13 Změna poměrného přetvoření v betonu bezprostředně po vyřezání otvoru (síla $100 \mathrm{kN}$ ). 


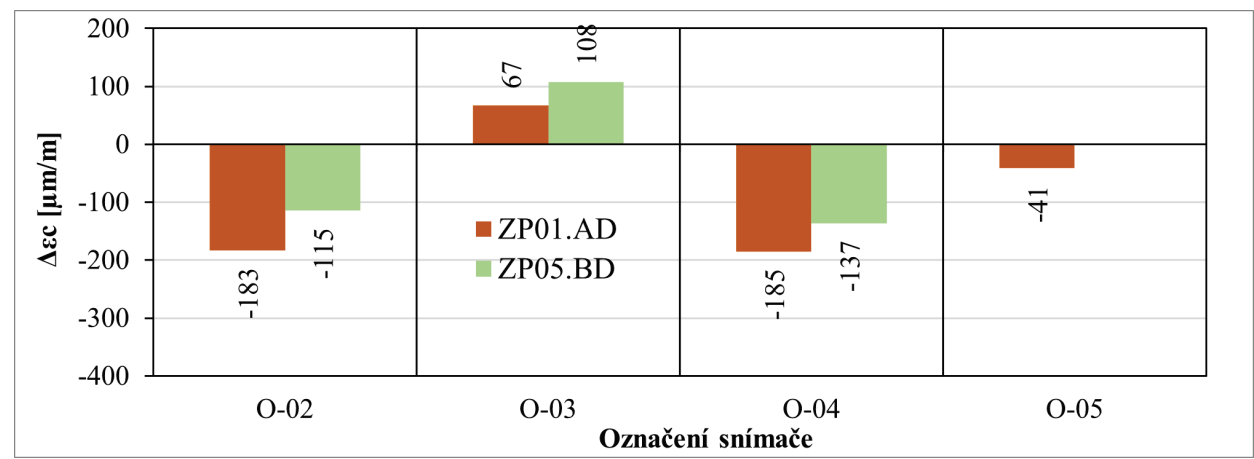

Obr. 14 Změna poměrného přetvoření v betonu 7 dnů po vyřezání otvoru (síla $100 \mathrm{kN}$ ).

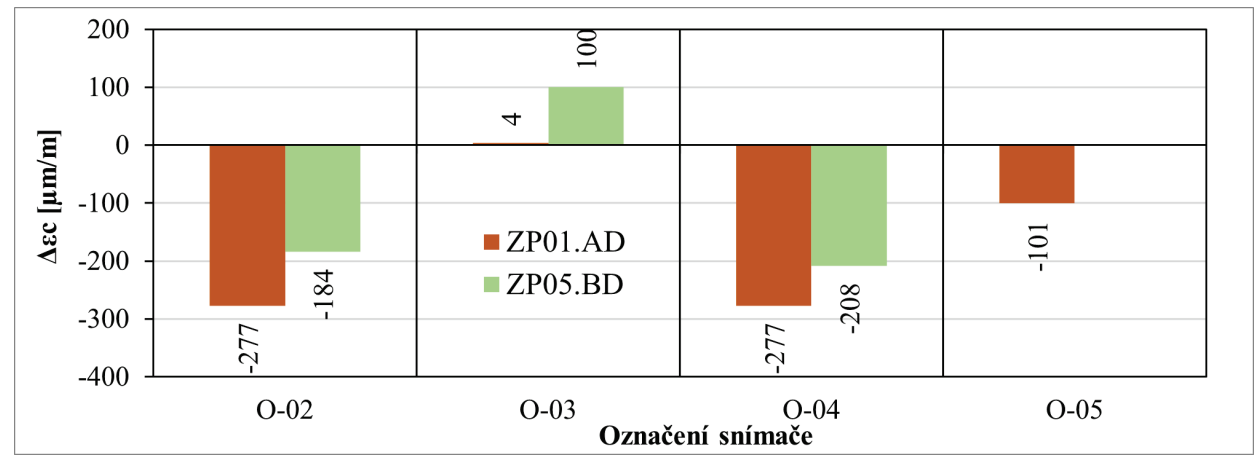

Obr. 15 Změna poměrného přetvoření v betonu 30 dnů po vyřezání otvoru (síla 100 kN).

\section{Šířky trhlin}

V průběhu experimentů byl monitorován průběh rozvoje trhlin ve zkušebních panelech, viz Obr. 9. Trhliny byly odečítány strunovými tenzometry a př́ložným měřítkem.

Ve všech vzorcích a pro všechny varianty zatížení vznikly po vyřezání otvoru trhliny. V nadpraží vznikly v místě tahových namáhání pro panely ZP02 trhliny šířky $0,3-0,7 \mathrm{~mm}$. Pro panely ZP03 byly trhliny v nadpraží šírky 0,1 - 0,3 mm, pro ZP04 a ZP05 pak 0,1 - 0,2 mm.

Pro panely ZP03, ZP04 a ZP05 vznikaly v nadpraží smykové trhliny, směrující směrem od vnitřního líce pilírư k nadpraží. Velikost těchto trhlin byla $0,1-0,2 \mathrm{~mm}$ pro všechny vzorky. Sklon těchto trhlin byl $45^{\circ}-61^{\circ}$ pro $\mathrm{ZP} 03$ a $55^{\circ}-72^{\circ}$ pro ZP04 a ZP05.

V pilírích ZP02 vznikly na vnějším lící v úrovní spodní hrany nadpraží trhliny šířky $0,1-0,25$ mm. Pro panely ZP03, ZP04 a ZP05 vzniky trhliny 0,1 - 0,15 mm.

Ve variantě experimentu „dlouhodobé sledování“ vznikaly v panelech ZP01 a ZP05 trhliny jen v nadpraží a v menším rozsahu, než u varianty „krátkodobé sledování“. Bezprostředně po vyřezání otvoru vznikaly šiřky trhlin $0,2-0,3 \mathrm{~mm}$ pro ZP01 a $0,1-0,15 \mathrm{~mm}$ pro ZP05. V průběhu dlouhodobého sledování se do 30 dnů od vyřezání otvoru trhliny rozšířily na 0,25 - 0,4 pro ZP01 bez vzniku dalších trhlin. Pro ZP05 se trhliny zvětšily na šiřku $0,1-0,2 \mathrm{~mm}$, k tomu vznikly i další trhliny o šírkách $0,05-0,1 \mathrm{~mm}$, avšak v minimálním rozsahu. Do konce sledování ( 87 dnů po vyřezání) se již trhliny dále nerozšiřovaly. 


\section{DISKUZE}

Hodnoty poměrných přetvoření na čidlech O-02 a O-04 u panelů ZP02.A, ZP03.A a ZP03.B jsou přibližně stejné, a to právě díky absenci spící výztuže v nově vzniklých pilírích. Hodnoty na čidlech O-02 a O-04 po vyřezání u panelu ZP02.B jsou pravděpodobně zkreslené. Možné vysvětlení je, že panel nebyl zatížen přesně v jeho rovině, a tak v panelu vznikal ohybový moment na vnitřní straně panelu (tam kde byly umístěny tenzometry).

Poměrné přetvoření na pilíŕích je menší u panelů ZP04 a ZP05 oproti panelů ZP02 a ZP03, díky prrítomnosti spící výztuže ve vnitřní časti pilíře (u budoucího otvoru).

Změny poměrných přetvoření pro paty pilírư (čidla O-05 a S-05) byly ihned po vyřezání otvoru minimální (do cca $-20 \mu \mathrm{m} / \mathrm{m}$ ). Je zřejmě, že v zatížené stěně bez otvoru vznikal tzv. „klenbový efekt“", kdy se zatížení přenášelo spíše do krajů panelů, tedy budoucích pilírư.

Šířky trhlin po vyřezání otvoru jsou menší u více vyztužených panelů (ZP03, ZP04 a ZP05) než u méně vyztužených panelů (ZP01 a ZP02). To právě díky přítomnosti výztuže v místech tahových namáhání. Z hlediska dlouhodobého bylo ověřeno, že po vyřezání otvoru nedocházelo u panelů ZP05 k výraznému zvětšování šířek trhlin. Chování panelů zůstalo stabilní, došlo jen k velmi mírnému rozvoji trhlin.

\section{ZÁV̌̌R}

Po vyřezání otvoru se ukázalo, že panely, jejichž pilíře byly vyztuženy spící výztuží (ZP04 a ZP05), vykazovaly menší přetvoření (a tím i napjatost) po vyřezání otvoru než panely bez této výztuže (ZP01, ZP02, ZP03), stejně tak i z dlouhodobého hlediska.

Ukázalo se, že panely, u niž byla navržena obvodová výztuž a spodní výztuž v nadpraží (ZP03, ZP04 a ZP05), vykazovaly podstatně menší šířky trhliny než panely vyztužené jen kari sítí (ZP01), př́padně panely jen s obvodovou výztuží (ZP02). Nejmenší šířky trhlin byly dosaženy u panelů ZP04 a ZP05 (cca 0,1-0,2 mm). Tato šiřka představuje běžné šiřky trhliny v železobetonu. Ukazuje to i na vhodnost použití tzv. „spící výztuže“(dopředu zabudované) v místě možného nového otvoru.

Zvolená velikost otvoru pro zkoušky $(1,2 \times 1,1 \mathrm{~m})$ ve skutečnosti představuje otvor o velikosti $2,4 \times 2,2 \mathrm{~m}$. Zvolený půdorysný rozměr otvoru $(2,4 \mathrm{~m})$ tak představuje poměrně velký zásah do běžné stěny. Je evidentní, že navržená spící (skrytá) výztuž v pilířích i v nadpražích splnila spoji úlohu, zajistila statické chování celého panelu. V průběhu vyřezání otvorů došlo $\mathrm{k}$ její aktivaci.

\section{Poděkování}

Článek byl řešen v rámci projektu TH03020446 Vývoj dispozičně variabilnější panelové soustavy pro bytové domy s finanční podporou TA ČR.

\section{Použité zdroje}

[1] HORÁČEK, Evžen a kol. Směrnice pro navrhování nosné konstrukce panelových budov: díl 1. Praha: Výzkumný ústav pozemních staveb Praha, 1972.

[2] ČSN EN 1992-1-1 ed. 2: Eurokód 2: Navrhování betonových konstrukcí - Část 1-1: Obecná pravidla a pravidla pro pozemní stavby. Praha: ÚNMZ, 2011.

[3] WITZANY, Jiří, Jaromír VRBA a Václav HONZÍK. Otvory v panelových domech. Praha: Pro Českou komoru autorizovaných inženýrů a techniků činných ve výstavbě vydalo Informační centrum ČKAIT, 2014. Technická knižnice (ČKAIT). ISBN 978-80-87438-55-8.

[4] WITZANY, Jiří a kol. Certifikovaná metodika: Metodické a technické pokyny pro posuzování stavebních úprav a zásahů do nosné konstrukce panelových domů. Praha, 2016.

[5] POPESCU, Cosmin, Gabriel SAS, Cristian SABĂU a Thomas BLANKSVÄRD. Effect of Cut-Out Openings on the Axial Strength of Concrete Walls. Journal of Structural Engineering [online]. 2016, 142(11) [cit. 2021-01-12]. ISSN 0733-9445. Dostupné z: doi:10.1061/(ASCE)ST.1943$541 X .0001558$

[6] SABAU, Cristian, Cosmin POPESCU, Niklas BAGGE, Gabriel SAS, Thomas BLANKSVÄRD a Björn TÄLJSTEN. Local and global behavior of walls with cut-out openings in multi-story reinforced concrete buildings. Engineering Structures [online]. 2019, 187, 57-72 [cit. 2021-01-12]. ISSN 01410296. Dostupné z: doi:10.1016/j.engstruct.2019.02.046

[7] BAŽANT, Zdeněk, Jiří STRNAD a Miloš ZICH. Ke stavu, poruchám, rekonstrukcím a úpravám panelových objektů. Beton TKS, 2017, roč. 17, č. 3, 8-12 [cit. 2021-01-25]. ISSN 1213-3116. 